\title{
PEMBINAAN KARAKTER MELALUI KETELADANAN \\ GURU PENDIDIKAN KEWARGANEGARAAN \\ DI SEKOLAH ISLAM AL AZHAR YOGYAKARTA
}

\author{
D anang Prasetyo dan Marzuki \\ Program Pascasarjana Universitas N egeri Yogyakarta \\ email: danang.ppsuny@gmail.com
}

\begin{abstract}
A bstrak: Penelitian ini bertujuan untuk mengungkap pembinaan karakter melalui keteladanan guru Pendidikan Kewarganegaraan di Sekolah Islam Al Azhar Yogyakarta. Penelitian ini merupakan penelitian deskriptif dengan pendekatan kualitatif. Subjek penelitian adalah guru Pendidikan Kewarganegaraan dan Kepala Sekolah di Sekolah Islam AI Azhar Yogya-karta. Pengumpulan data dengan teknik wawancara, observasi, dan dokumentasi. Pemeriksaan keabsahan data dilakukan dengan triangulasi sumber. Analisis data dilakukan secara kualitatif melalui tahap pengumpulan data, reduksi data, penyajian data, dan penarikan kesimpulan. Hasil penelitian menunjukkan bahwa guru Pendidikan Kewarganegaraan di Sekolah Islam Al Azhar Yogyakarta melakukan pendidikan karakter melalui keteladanan berupa tutur kata, ciri kepribadian, sikap, dan penampilan yang sesuai dengan karakter religius, disiplin, demokratis, semangat kebangsaan, cinta tanah air, cinta damai, peduli lingkungan, dan peduli sosial.
\end{abstract}

Kata Kunci: pembinaan karakter, keteladanan guru, pendidikan kewarganegaraan

\section{BUILDING CHARACTER THROUGH THE EXAMPLE OF CITIZEN SHIP EDUCATION TEACHERS IN AL AZHAR ISLAMIC SCHOOL OF YOGYAKARTA}

\begin{abstract}
A bstract: This research aims to reveral the character building through the example of citizenship education teachers in AI Azhar Islamic School of Yogyakarta. This research was qualitative research using the descriptive approach. The subjects of the research were citizenship education teachers and principal of AI Azhar Islamic School of Yogyakarta. The data were collected through interviews, observation, and documentation. The data validation was done by triangulation. The result of this study is as follows citizenship education teachers in AI Azhar Islamic School of Yogyakarta build student's character through the exemplary form of speech, personality traits, attitudes, and performance of being suitable for the character of religiousity, discipline, democracy, the spirit of nationalism, patriotism, love of peace, environmental care, and care of society.
\end{abstract}

Keyw ords: character building, example of teachers, civic education

\section{PENDAHULUAN}

Pendidikan nasional berfungsi mengembangkan kemampuan, membentuk watak, serta membangun peradaban bangsa yang bermartabat dalam rangka mencerdaskan kehidupan bangsa. Pendidikan yang bermartabat bertujuan untuk berkembangnya potensi siswa supaya menjadi manusia yang beriman dan bertakwa kepada Tuhan YangMahaEsa, berakhlak mulia, sehat, ber- ilmu, cakap, kreatif, mandiri, dan menjadi warga negara yang demokratis serta bertanggung jawab. Namun, secara umum pelaksanaan pendidikan formal di sekolah be lum berhasil mengemban tugas dalam membangun insan yang berbudi luhur sebagaimana diamanatkan Pasal 3 Undang-Undang N omor 20 Tahun 2003 tentang Sistem Pendidikan Nasional. Ketidakberhasilan membangun insan berbudi luhur tersebut 
dapat dilihat dari maraknya fenomena tawuran pelajar, adanya pelajar yang suka mencontek, bullying verbal/ fisik oleh teman sebaya, dan pelajar sering membolos (Sudiatmika, 2013:324).

Fenomena ini dikuatkan dengan data anak berhadapan dengan hukum tingkat nasional. Komisi Perlindungan Anak Indonesia (KPAI) mencatat jumlah kasus anak yang berhadapan dengan hukum dari 2011 hingga April 2015 sebanyak 6.006 kasus (Setyawan, 2015). Selain itu, Sujatmiko (2015) memaparkan kasus kenakalan remaja di Daerah Istimewa Yogyakarta (DIY) yang semakin kompleks. Kasus di Yogyakarta bukan hanya masalah tawuran pelajar saja, namun sudah menjurus ke tindak kriminal. Berdasarkan data yang dimiliki Panti Sosial Bina Remaja DIY, jumlah anak yang berhadapan dengan hukum terus meningkat. Tahun 2011, PSBR DIY menangani sebanyak 20 anak. Tahun berikutnya (2012) mengalami peningkatan cukup signifikan, yakni menjadi 105 anak. Pada tahun 2013 jumlah kasusnya terus naik menjadi 174 anak dan tahun 2014 menjadi 216 anak.

Data dan fenomena tersebut menunjukkan bahwa pendidikan selama ini be lum sepenuhnya berhasil pada aspek pembinaan karakter. Sekolah sebagai lembaga pendidikanformal terlalu terpesona dengan target-target akademis dan melupakan urgensi pembinaan karakter. Fenomena pendidikan formal yang hanya berorientasi pada pengetahuan juga dipaparkan oleh Supeni \& Saddhono (2013:156) sebagai berikut.

N owadays, the life of school, especially the elementary school experiences the degradation in humanism. Teachers are busy in giving lesson such as mathematics, language, physics, and biology. They put their orientation on cognitive achievement. They treat the students as the objects who must master the knowledge by passive cognitive activity to prepare school and national examinations.
Teachers tend to deliver material, and focus on cognitive aspect without developing the students attitude and life values. Students as person do not get enough attention, therefore the knowledge that they master is not meaningful for themselves, life, and humanism.

Pendapat tersebut menegaskan bahwa guru di sekolah lebih sibuk memberikan pelajaran yang berorientasi kognitif, seperti pelajaran matematika, bahasa, fisika, dan biologi. Pendidikan sekolah formal hanya meletakkan orientasi pada prestasi kognitif dan menganggap siswa sebagai objek yang harus menguasai pengetahuan dengan aktivitas kognitif pasif. Orientasi ini semata-mata untuk mempersiapkan ujian sekolah dan ujian nasional sehingga dapat mengabaikan aspek perkembangan sikap dan nilai-nilai kehidupan.

Orientasi pendidikan di Indonesia pada pencapaian kognitif juga belum membuahkan hasil yang memuaskan. Hal ini menambah catatan hitam pendidikan. Berdasarkan survei yang dilakukan oleh O rganization for Economic Cooperation and Development (OECD) terhadap hasil tes di 76 negara, Indonesia berada pada posisi ke-69. Peringkat ini didasarkan pada mapel matematika dan science pada saat anak berusia 15 tahun (Coughlan, 2015). Keadaan seperti ini membuktikan bahwa pendidikan yang berorientasi pada kemampuan kognitif saja belum membuahkan hasil, terlebih lagi pada aspek pendidikan karakter.

Di lain pihak, ada persepsi bahwa tugas dan tanggung jawab terhadap baik buruknya karakter/ moralitas pelajar semata-mata hanya dipercayakan kepada guru Pendidikan Pancasila dan Kewarganegaraan (PPKn) dan guru Pendidikan Agama. Khususuntukpelajaran PPKn, alokasi waktu yang disediakan sangat terbatas, yakni hanya 2 jam pelajaran (untuk KTSP 2006) dan 3 jam pelajaran (untuk Kurikulum 2013) setiap minggunya. Bahkan, tuduhan 
lain juga sering ditujukan pada sekolah, yang dirasa kurang memberikan pendidikan agama dan karakter yang baik (Setyawan, 2014).

Pendidikan karakter dapat dilakukan dengan berbagai metode sebagaimana dinyatakan oleh Kirschenbaum (1995:6) yang dikelompokkan menjadi empat, yaitu penanaman nilai, keteladanan nilai, fasilitasi nilai, dan keterampilan nilai. Setiap metode mempunyai berbagai strategi untuk pelaksanaannya.

Keteladanan menjadi sangat penting untuk mengatasi masalah karakter dan memiliki kontribusi yang sangat besar dalam mendidik dan membina karakter. Keteladanan lebih mengedepankan aspek perilaku dalam bentuk tindakan nyata daripada sekedar berbicara. Strategi atau metode ke teladanan dalam pembinaan karakter menjadi bagian dari pendekatan komprehensif yang merupakan sintesis dari dua metode tradisional, yaitu: (1) metode inkulkasi (penanaman) nilai dengan pemberian teladan; dan (2) metode kontemporer dengan fasilitasi nilai melalui keterampilan hidup (live skills) (Widyaningsih, Zamroni \& Zuchdi, 2014:189).

Pembinaan karakter perlu dilakukan secara intensif di sekolah, termasuk SekoIah Islam Al Azhar. Yogyakarta yang dijuluki "Kota Pelajar" memiliki banyak sekolah/ yayasan pendidikan, baik yang bercorak nasionalis maupun religius. Seiring perkembangan zaman, bermunculan sekolah-sekolah swasta yang menjadi sekolah unggulan dengan mutu dan fasilitas yang jauh lebih baik dibandingkan sekolah negeri, seperti halnya sekolah-sekolah AI Azhar (Triyansyah, 2015). Sekolah Islam AI Azhar Yogyakarta menjadi salah satu yayasan pendidikan formal yang peduli terhadap pembinaan karakter yang bercorak Islami sekaligus berbudaya.
Bukti lain keunggulan Al Azhar Yogyakarta adalah penilaian positif orang tual wali siswa dan masyarakat Yogyakarta terhadap Sekolah Islam AI Azhar Yogyakarta. Salah satu orang tua/ wali yang merasa banggamenyekolahkan anaknya di SMP Islam A I A zhar 26 Yogyakarta adalah Karim (2012). Beliau memberikan penilaian positif bahwa saat anaknya sekolah di Al Azhar tidak ada lagi kemalasan untuk berangkat ke sekolah, ia selalu gembira setiba di rumah, atau dengan kata lain anak sangat menikmati kesehariannya di sekolah. Se lain itu, kemampuan anak berbahasa Inggris semakin meningkat dan termanfaatkan dengan baik. Setiap siswa di Al Azhar didorong untuk memupuk prestasi sesuai dengan minat dan bakat masing-masing dan tidak mengenal pedoman kata 'pokoknya'. $\mathrm{Hal}$ inilah yang menjadi salah satu dasar peneliti mengungkap cara Sekolah Islam AI Azhar Yogyakarta dalam melakukan pembinaan karakter.

Menurut pemaparan Bowo Sidarto, salah seorang guru PKn di SMA Islam AIAzhar 9 Yogyakarta, strategi pembinaan karakter yang diterapkan sekolah Al A zhar Yogyakartayaitu melalui keteladanan guru. Guru menempatkan diri sebagai role model bagi peserta didik di sekolah. Selama ini strategi tersebut dinilai sangat efektif dan membuahkan hasil. Terbukti sejak Sekolah Islam Al Azhar berdiri di Yogyakarta, be Ium pernah nama Al A zhar Yogyakarta dikaitkan dengan perilaku tidak bermoral dari warga sekolah baik guru, karyawan, maupun peserta didik. Bowo Sidarto juga menuturkan bahwa belum pernah ada anak yang bersekolah di Al Azhar bermasalah dengan hukum, melakukan tawuran, dan melakukan kenakalan remaja lainnya yang dapat merusak citra Al Azhar. Guru Al Azhar tidak pernah tersangkut masalah pelecehan seksual dan sosial, kriminalitas/ 
kejahatan, atau bahkan kecurangan bidang akademik. Ini sebagai bukti guru di Al Azhar sudah selayaknya dijadikan teladan. A pabila dibandingkan dengan sekolah-sekolah negeri atau swasta, maka sekolahsekolah Al Azhar mempunyai citra yang lebih baik dalam mendidik anak dan menghasilkan lulusan yang cerdas sekaligus berkarakter.

Strategi pembinaan karakter didukung dengan tata tertib sekolah yang wajib dipatuhi seluruh warga sekolah. Seluruh warga sekolah mempunyai tanggungjawab untuk menjaga nama baik Sekolah Islam AI Azhar Yogyakarta. Bowo mengemukakan bahwa keberhasilan pendidikan karakter di sekolah Al Azhar sangat ditentukan oleh keteladanan dari guru. Akan tetapi, guru tidak akan pernah berhasil menjadi teladan baik, jika hanya berusaha menjadi pribadi yang baik di sekolah, dan tidak baik di tengah masyarakat. Sikap guru di sekolah dan di luar sekolah akan memengaruhi caranya meyakinkan dan memengaruhi para peserta didik. Karena tidak menutup kemungkinan guru berinteraksi dengan peserta didik di luar sekolah dan di luar kegiatan pembelajaran di sekolah.

Asih Rusmi, selaku guru PKn SMP Islam AI Azhar 26 Yogyakarta, sependapat dengan pernyataan di atas. Beliau menyatakan bahwa guru di sekolah layaknya orang tua peserta didik sehingga guru merupakan cerminan kepribadian anak. Pedoman tersebut menuntut guru mampu menjadi teladan yang baik. Orang tua/ wali siswa telah percaya untuk menyekolahkan anaknya di Al Azhar dengan harapan menjadi lebih baik dalam ilmu dan karakternya. Harapan tersebut harus terwujud setelah lulus dari AI Azhar.

Berdasarkan paparan di atas, peneliti tertarik untuk meneliti dan mengungkap lebih dalam cara atau strategi pembinaan karater di Sekolah Islam Al Azhar Yogyakarta melalui keteladanan guru Pendidikan Kewarganegaraan. Oleh karena itu, penelitian bertujuan untuk mengungkap strategi pembinaan karakter di Sekolah Islam AI Azhar Yogyakarta melalui keteladan guru Pendidikan Kewarganegaraan (PKn).

Alasan kuat peneliti memilih guru PKn sebagai subjek penelitian karena PKn dan pendidikan karakter merupakan satu kesatuan yang utuh, sebagaimana gagasan Arthur, Davison \& Lewis (2005:239) yang menegaskan, "Character education is a specific approach to morals or values education, which is consistently linked with citizenship education". Pendidikan karakter berarti merupakan pendekatan khusus untuk pendidikan moral dan pendidikan nilai. Pendidikan karakter juga sangat terkait dengan Pendidikan Kewarganegaraan.

Tulisan Arthur, Davies \& Hahn (2008: 410) yang berjudul Educating for Civic Character menyimpulkan, "Integrating character education and civic education is one step toward such a comprehensive and effective approach". Ini berarti bahwa integrasi antara pendidikan karakter dan pendidikan kewarganegaan menjadi satu pendekatan yang efektif dan komprehensif dalam pendidikan.

Samsuri (2012:15) juga sependapat dengan gagasan Arthur yang menyatakan bahwa pendidikan kewarganegaraan memiliki dimensi yang tidak dapat dilepaskan dari aspek pembentukan karakter dan moralitas warga negara. Siagian (2013:18) le bih memperkuat bahwa pendidikan karakter merupakan faktor utama yang diperlukan dalam pembangunan warga negara ideal. Selain itu, pendidikan kewarganegaraan mempunyai kontribusi untuk mencegah terjadinya kenakalan remaja. 


\section{METODE}

Penelitian ini merupakan penelitian deskriptif kualitatif. Penelitian dilaksanakan di Sekolah Islam AI Azhar Yogyakarta yang melingkupi SD Islam Al Azhar 31, SMP Islam AI Azhar 26, dan SMA Islam AI Azhar 9 Yogyakarta. Alasan dipilinnya setting tempat di Sekolah Islam Al Azhar Yogyakarta karena keberhasilannya dalam melakukan pembinaan karakter peserta didik. Pernyataan tersebut dibuktikan saat peneliti melakukan pra-research. Adapun waktu penelitian ini dimulai bulan September 2015 sampai bulan M ei 2016.

Penentuan subjek penelitian dilakukan dengan cara purposive yang disesuaikan dengan tujuan penelitian (Sugiyono, 2013:301). Subjek penelitian ditentukan berdasarkan orang yang dianggap paling tahu tentang informasi yang dibutuhkan dalam penelitian sehingga akan memudahkan peneliti dalam mengungkap tujuan penelitian. Oleh karena itu, subjek penelitian yang sesuai adalah guru dan kepala sekolah yang terkait erat dengan keteladanan. Adapun guru yang dipilih adalah guru Pendidikan Kewarganegaraan di Sekolah Islam Al Azhar Yogyakarta, dengan pertimbangan bahwa guru PKn menjadi salah satu guru yang memiliki tanggung jawab besar dalam pendidikan karakter seperti halnya guru Pendidikan Agama.

Pengumpulan data dalam penelitian ini dengan teknik wawancara mendalam, observasi, dan studi dokumen. Peneliti merupakan instrumen utama penelitian. Peneliti sekaligus sebagai perencana yang menetapkan fokus penelitian, memilih informan, sebagai pelaksana pengumpulan data, menafsirkan data, menarik kesimpulan se mentara, dan menganalisis data di lapangan yang alami (Djaelani, 2013: 84).

Pemeriksaan keabsahan data penelitian dengan triangulasi. Dalam penelitian ini, triangulasi yang dianggap relevan untuk menguji keabsahan data adalah triangulasi teknik dan sumber. Triangulasi teknik digunakan untuk menguji kredibilitas data yang dilakukan dengan cara mengecek data pada sumber yang sama dengan teknik yang berbeda. Dalam penelitian ini, triangulasi teknik dilakukan dengan mengecek data yang diperoleh melalui wawancara dengan data hasil observasi dan studi dokumen. Langkah pertama, peneliti melakukan wawancara dengan kepala sekolah dan guru PKn di Sekolah Islam AI Azhar Yogyakarta. Peneliti kemudian melakukan pengamatan langsung dan melakukan studi dokumen. Dengan demikian, dalam penelitian ini peneliti juga menggunakan triangulasi teknik, yaitu dengan wawancara, observasi, dan studi dokumen untuk memastikan keabsahan data yang diperoleh.

Selain itu, untuk memenuhi keabsahan data, dilakukan juga triangulasi sumber. Triangulasi sumber berarti membandingkan dan mengecek balik derajat kepercayaan suatu informasi yang diperoleh melalui waktu dan alat yang berbeda dalam penelitian kualitatif (Moleong, 2007:29). Dalam penelitian ini triangulasi sumber dilakukan dengan cara membandingkan hasil wawancara dengan kepala sekolah dengan hasil wawancara dengan guru Pendidikan Kewarganegaraan di SD Islam Al Azhar 31, SMP Al Azhar 26, dan SMA Al Azhar 9. Data yang terkumpul dan yang dianggap sah, kemudian dianalisis dengan teknik teknik analisis deskriptif kualitatif.

\section{HASIL DAN PEMBAHASAN}

Sebagai sosok teladan di sekolah, guru di Sekolah Islam Al Azhar berusaha menunjukkan tutur kata, sifat, dan sikap baik supaya memberikan dampak yang baik pula terhadap siswa. BSD, AR, SF, FK 
sebagai guru PKn di Sekolah Islam Al Azhar Yogyakarta sependapat bahwa guru Al Azhar berusaha berkarakter sebagaimana karakter-karakter yang telah dicanangkan oleh pemerintah melalui Kementerian Pendidikan dan Kebudayaan. Meski mengacu kepada 18 karakter yang ditargetkan, namun tidak semua karakter tersebut dapat terlaksana dengan sempurna. Salah satu cara yang tepat untuk melakukan pembinaan karakter sesuai dengan nilainilai tersebut yaitu melalui keteladanan guru.

Prinsip guru Al Azhar Yogyakarta adalah berkarakter terlebih dahulu sebelum melakukan pembinaan karakter terhadap peserta didik. Adapun keteladanan guru Pendidikan Kewarganegaraan sebagai upaya pembinaan karakter peserta didik Al Azhar dapat dijabarkan sebagai be rikut.

\section{Keteladanan Religius}

Konsep keteladanan karakter religius tersebut diterapkan oleh guru di lingkungan sekolah Al Azhar yang melaksanakan pembinaan karakter religius melalui keteladanan. Sebagaimana pernyataan BSD (wawancara, Kamis, 19/11/2015) pembinaan karakter dilakukan dengan mengisi waktu luang (jeda pergantian jam pelajaran) dengan tadarus Alquran. Tadarus tersebut dapat dilakukan di masjid Al Azhar sebeIum salat Zuhur berjamaah atau di ruang guru saat pergantian jam pelajaran. Kegiatan tersebut tidak hanya dilakukan oleh guru Pendidikan Agama dan guru PKn, namun sebagian besar guru melaksanakannya. Pernyataan tersebut juga terbukti dilakukan berdasarkan hasil observasi (19/ 11/ 2015). Pada saat peneliti datang ke sekolah untuk melakukan wawancara tampak guru Pendidikan Agama dan guru- guru yang lain sedang tadarus Alquran di ruang guru.

Pernyataan serupa juga dikemukakan oleh AR (wawancara, 20/ 11/ 2015) yang membenarkan kegiatan tadarus sebagai kegiatan rutin yang biasa dilakukan saat waktu luang. Selain untuk menambah hafalan surat/ ayat Alquran, kegiatan tersebut jugauntuk memantapkan kemajuan hafalan bagi guru yang akan dipantau oleh guru Pendidikan Agama sebagai penanggung jawab kegiatan hafalan Alquran. Setiap guru wajib ujian hafalan pada guru Pendidikan Agama minimal seminggu sekali.

Kegiatan tadarus juga dapat dilakukan oleh guru di masjid AI Azhar sebelum salat Zuhur berjamaah, seperti yang biasa dilakukan oleh BSD. Apabila tadarus sebelum salat Zuhur, beliau akan berusaha menjadi muazin salat. Begitu juga yang dilakukan oleh guru-guru lain. Mereka datang lebih awal ke masjid saat waktu luang dan salah satu dari mereka menjadi muazin. Namun, apabila ada peserta didik laki-laki yang datang paling awal, maka ia akan diberikan kesempatan menjadi muazin supaya ia memiliki pengalaman yang berharga. Kesempatan ini memberikan daya tarik tersendiri bagi peserta didik laki-laki untuk datang lebih awal dan menjadi muazin.

Guru yang memiliki jam mengajar yang banyak hingga jam mengajarnya mendekati waktu salat Zuhur, ia akan mengakhiri pembelajarannya segera dan memberikan kesempatan kepada peserta didik untuk segera ke masjid. Guru pun mendampingi para peserta didik dan memberikan contoh untuk datang lebih awal dan segera berwudu, melaksanakan salat sunah, dan duduk di baris paling depan untuk bersiap melaksanakan salat berjamaah. Rutinitas tersebut juga terlaksana pada sa- 
lat Asar berjamaah saat siswa mengikuti kegiatan ekstrakurikuler.

AR (wawancara, 23/ 10/ 2015) menyatakan bahwa sebagai bekal memimpin hafalan siswa sebagai bentuk pembinaan karakter religius, guru Al Azhar harus le bih dulu hafal Juz 30 dari A lquran. Hafalan Juz 30 dibimbing oleh guru agama dan dipantau kemajuannya dengan kartu bimbingan. Apabila sudah mampu hafal Juz 30, maka dilanjutkan hafalan Juz 29 dan seterusnya. Cara yang dapat dilakukan guru Al Azhar untuk mencapai hafalan tersebut dengan melakukan tadarus saat waktu luang. Selain itu, untuk membiasakan diri berpuasa, beliau mengajak para peserta didik terutama yang diampunya untuk rutin melaksanakan puasa sunah Senin dan Kamis.

Banyaknya kegiatan keagamaan di Al Azhar memiliki dampak positif terhadap religiusitas guru. Hal ini dikarenakan semua guru memiliki tanggung jawab yang sama dalam membina nilai-nilai keIslaman peserta didik. Konsekuensi demikian menjadikan guru harus lebih paham dan menguasai niali-nilai ke-Islaman tersebut. Seperti yang disampaikan SF (wawancara, 30/ 10/ 2015) bahwa sebelum melakukan pendampingan terhadap siswa, guru haruslebihdulu menguasai ilmu dan mempraktikkannya. Misalnya dalam pendampingan hafalan bacaan salat dan tadarus Alquran, guru harus lebih dulu menguasainya. Cara yang dilakukan dengan setoran hafalan kepada guru Pendidikan Agama Islam minimal satu kali dalam seminggu. Cara tersebut menjadi salah satu bukti keteladanan kepada siswa bahwa guru lebih dahulu melakukan apa yang dianjurkan kepada siswanya. Sebelum membina siswa untuk menjadi pribadi muslim, guru harus berusaha menjadi pribadi yang religius.
Guru yang religius juga dapat diwujudkan dalam kegiatan pembelajaran, misalnya selalu memulai dan mengakhiri pembelajaran dengan berdoa. Cara berdoa yang dilakukan tentu dengan khusuk. Selain itu, Siti Fatonah juga memaparkan usaha beliau untuk membentuk keteladanan religius dari segi penampilan. Penampilan yang ditunjukan dengan cara rapi menggunakan jilbab, tidak terlihat rambutnya, dan tidak memakai seragam kerja yang ketat. Cara ini untuk memberikan contoh bagaimana cara berpakaian yang benar dan Islami bagi siswa yang muslimah.

Bagi FK (wawancara, 8/ 3/ 2016) menjadi sosok religius bagi siswa dapat dilakukan setiap hari. Sebagai wali kelas VI yang wajib mendampingi siswa setiap saat, be liau menunjukkannya dengan perbuatan nyata. Misalnya saja ikut salat berjamaah di masjid bersama siswa, selalu mengucapkan salam saat memasuki ruang kelas dan berdoa saat memulai dan mengakhiri pembelajaran. Di samping itu, untuk wali kelas di SD AI Azhar 31 disediakan meja kerja yang berada dalam satu ruang kelas, sehingga apa yang dilakukan guru dapat diamati oleh siswa.

Beberapa contoh sikap dan perilaku religius guru yang dipaparkan di atas merupakan cara yang dianjurkan oleh Al Azhar Yogyakarta dalam melakukan pembinaan karakter siswa. Harapannya supaya siswa beribadah tepat waktu, selalu memulai dan mengakhiri sesuatu dengan berdoa, memahami bacaan dan gerakan salat, mampu membaca dan mengamalkan Alquran dengan baik dan benar, serta berpakaian secara Islami.

Saat ini dapat dikatakan bahwa pembinaan karakter religius di Al Azhar Yogyakarta berhasil. Sebagai buktinya siswa telah sadar salat Duha berjamaah pada jam istirahat pertama dan salat Zuhur pada jam 
istirahat kedua tepat waktu, tertib, dan khusuk. Siswa pun segera bergegas untuk datang lebih awal untuk menjadi muazin dan bertadarus sebelum azan. Selain itu, cara berpakaian siswa baik putra maupun putri sudah dikatakan sesuai ajaran Islam, yakni menutup aurat dengan baik (observasi, 8/ 3/ 2016).

\section{Keteladanan Karakter Disiplin}

BSD (wawancara, 19/11/ 2015) me ngemukakan bahwa karakter disiplin yang ingin dikembangkan di sekolah adalah kesediaan semua warga sekolah untuk mematuhi peraturan yang berlaku di Al Azhar. Disiplin berarti menaati atau mematuhi aturan dan tata tertib yang telah disepakati bersama. Baik disiplin tugas guru, disiplin waktu, dan semua hal yang berkaitan dengan profesi seorang guru. Beliau berusaha untuk tidak meninggalkan jam pelajaran kecuali kepentingan yang mendesak. Apabila terpaksa ia tidak masuk, maka ia memohon izin kepada kepala sekolah dan ketua kelas serta memberikan tugas untuk dikumpulkan. Selain itu, tugas-tugas yang diberikan guru harus dengan segera dikoreksi, dinilai, dan dikembalikan kepada siswa.

Cara lain sebagai wujud guru yang memiliki karakter disiplin yaitu dengan kesediaan/ inisiatifuntuk mengisi jam kosong guru lain yang sedang sakit/ izin. Kegiatan ini untuk menambah materi pelajaran atau memberikan pendampingan siswa mengerjakan tugas yang diberikan oleh guru yang berhalangan hadir. Harapannya supaya siswa memiliki rasa untuk menghargai waktu dan berusaha sekuat tenaga untuk menghargai waktu dengan melakukan hal-hal yang positif dan berguna. Sikap disiplin se perti ini dapat memberi gambaran kepada siswa untuk memiliki semangat menghargai waktu dan tidak pernah meninggalkan kewajiban-kewajiban sebagai siswa di sekolah atau di rumah.

Keteladanan lain yang dilakukan oleh guru Al Azhar Yogyakarta yaitu dengan cara disiplin memakai seragam kerja sesuai ketentuan yang telah disepakati bersama. Pemakaian seragam bagi guru akan berdampak pada seragam siswa sehingga siswa akan berusaha selalu memakai seragam sekolah yang sudah ditentukan oleh sekolah. Siswa pun akan malu apabila salah/ lupa memakai seragam sekolah yang tidak sesuai harinya.

AR menambahkan beberapa contoh keteladanan guru yang berjiwa disiplin, seperti dengan menggunakan pakian yang rapi, saling koreksi kerapian guru dengan siswa, bahkan ada kebiasaan guru Al Azhar tidak akan memulai kegiatan pembelajaran apabila terdapat seragam siswa yang belum rapi. Selain itu, ia (AR) selalu datang ke sekolah sebelum pukul 6.30 setiap harinya dan tetap berada di sekolah/ stand by meski tidak ada jam mengajar untuk mendampingi siswa dalam kegiatan selain tatap muka di kelas dan selalu siap saat dibutuhkan siswa. Selain itu, karakter disiplin yang dilakukan oleh AR yaitu dengan cara menyampaikan hasil ulangan harian sebelum siswa menanyakan atau meminta. $\mathrm{Hal}$ ini dilakukan supaya ada kebanggaan pada diri siswa atas hasil belajar dan introspeksi diri apabila masih dirasa kurang. Kecepatan dan ketepatan menjadi kunci utama jiwa yang disiplin.

Pelaksanaan kewajiban oleh guru dengan cara demikian akan mampu menjadi contoh bagi siswa untuk melaksanakan kewajibannya tanpa harus diminta dan dipaksa. Misalnya saja siswa mengumpulkan tugas sekolah sesuai jadwal yang telah disepakati atau bahkan lebih awal lagi. Pembiasaan yang demikian bertujuan untuk menghilangkan kebiasaan menunda-nunda 
pekerjaan yang justru akan membuat semakin banyak pekerjaan yang harus diselesaikan. Begitu juga dengan SF (wawancara, 8/ 12/2015) yang berusaha berkomitmen menyampaikan hasil ulangan maksimal 3 (tiga) hari. A pabila selesai hasil ulangan dikoreksi sebelum batas waktu tersebut, SF akan segera menyampaikan kepada siswa saat istirahat melalui ketua kelas.

Sebagai wali kelas yang diwajibkan menempati meja kerja di dalam ruang kelas siswa yang diampunya, FK harus menunjukan sikap disiplin hadir ke sekolah (wawancara, 8/ 3/ 2016). Sebelum siswa datang ke sekolah dan memasuki ruang keIas, FK berusaha hadir terlebih dahulu dan menyambut siswa yang masuk ke ruang kelas. Sebelum pukul 6.45 WIB, ia sudah stand by di dalam ruang kelas dengan seragam kerja sesuai ketentuan.

Guru yang mampu menjadi teladan disiplin akan menyiapakan perlengkapan belajar mengajar sendiri, karena terkadang banyak guru yang suka memerintah siswa untuk mengambilkan buku atau perangkat pembelajaran lainnya. Target guru Al Azhar dalam membina karakter mandiri yakni supaya siswa dapat terbiasa menyiapkan peralatan belajar sendiri dan terbiasa menyelesaikan tugas tanpa tergantung kepada orang lain. Harapan guru dengan memberikan contoh atau keteladanan dalam pembinaan karakter disiplin akan menjadikan siswamampu mengaktualisasikan sikap disiplintersebut. Oleh karena itu, siswa mampu tepat waktu dalam beribadah, tidak terlambat untuk datang ke sekolah, tidak pernah absen/ tidak masuk kelas tanpa keterangan, tepat waktu mengerjakan dan mengumpulkan tugas sekolah, keluar masuk kelas minta izin guru, menaati kontrak belajar, role of class, peraturan sekolah, dan se Ialu memakai seragamsekolah dengan baik.
Selama melakukan pengamatan (observasi, 8/ 3/ 2016), peneliti tidak menemukan siswa Al Azhar Yogyakarta datang terlambat ke sekolah. Begitu juga dengan kedisiplinan siswa dalam memakai seragam sekolah, peneliti tidak menemukan siswa yang tidak seragam serta tidak ditemukan siswa yang berpakaian melanggar aturan sekolah. Bukti lain terlaksanannya pembinaan karakter disiplin bagi siswa yaitu memelihara dan menjaga peralatan sekolah dan bangunan dengan tidak mengotori, melakukan corat-coret, merusak, membawa buku pelajaran sesuai jadwal, membawa mukena bagi siswa putri, dan tidak meninggalkan buku pelajaran dan barang pribadi di lingkungan sekolah.

\section{Keteladanan Karakter D emokratis}

Pembinaan karakter demokratis di Al Azhar Yogyakarta menekankan musyawarah mufakat berdasarkan keberagaman. Guru Al Azhar berusaha menjadikan siswa sebagai subjek bukan sebagai objek belajar. Caraini supayamenciptakan dinamikapembelajaran yang terbuka, berkebebasan, dan bertanggung jawab. Hal ini ditegaskan oleh BSD (wawancara, 18/12/ 2015) memberikan contoh karakter demokratis, yakni dengan cara mengutamakan musyawarah dalam pembagian tugas sekolah yang sifatnyakelompok. Setelah guru memberikan topik dan garis besar tugas tersebut, guru memberikan kebebasan kepada para siswa untuk membagi kelompok berdasarkan cara yang telah disepakati

Keteladanan sikap demokratis yang secaralangsung terasa dalam kegiatan pembelajaran sehari-hari yakni dengan cara memberikan kesempatan kepada siswa untuk menyampaikan pendapat, bertanya, dan menjawab pertanyaan yang menjadi topik pembelajaran. Kegiatan ini juga secara langsung menumbuhkan sikap demokratis de- 
ngan cara menghargai pendapat orang lain yang sedang disampaikan, tanpa memotong pembicaraan, dan meninggalkan sifat emosional meski berbeda pendapat. Komunikasi belajar dua arah inilah yang menunjukkan bahwa siswa merupakan subjek belajar bukan lagi sebagai objek belajar yang pasif. Bukti lain sikap demokratis guru, yaitu menerima perbedaan pendapat yang disampaikan oleh siswa berkaitan dengan topik pelajaran yang sedang dibahas, atau bahkan menyanggah pernyataan guru di dalam kelas sehingga akan menciptakan ruang diskusi antara guru dan siswa untuk menemukan pemahaman baru yang baik dan benar. Guru harus mampu membuka ruang diskusi dengan semua warga sekolah, baik dengan sesama guru maupun dengan siswa.

Upaya guru mewujudkan nilai demokratis dalam kegiatan belajar mengajar dengan cara memperlakukan siswa secara sa$\mathrm{ma} /$ tidak membedakannya berdasar gender/ jenis kelamin, serta bentuk fisik dalam kegiatan belajar mengajar di kelas dan kegiatan di luar kelas. Misalnya guru memberikan kesempatan dan porsi yang sama untuk bertanya jawab dalam kegiatan diskusi. AR mengatakan, dalam membina karakter demokratis hampir sama dengan apa yang dilakukan oleh BSD, yakni menjadikan siswa sebagai subjek, bukan objek belajar. Cara yang dilakukan misalnya melakukan musyawarah tentang tata tertib kelas, kontrak belajar, dan pembentukan pengurus kelas di awal semester. Musyawarah ini menampung semua aspirasi siswa supaya siswa merasa aturan yang akan diikuti adalah hasil karya bersama. Harapannya siswa akan menerima dan melaksanakannya dengan rasa tanggung jawab.

Keteladanan karakter demokratisjuga diupayakan oleh SF, misalnya saat guru meminta siswa untuk mengevaluasi/ meni- lai kepribadian guru dan proses pembelajaran di kelas. Keteladanan yang dilakukan dengan cara menuliskan kritik dan saran melalui selembar kertas yang boleh diberi nama atau tidak. Cara ini dilakukan untuk membiasakan siswa memiliki kesempatan menyampaikan penilaiaan terhadap apa yang telah siswa rasakan (wawancara, 10/ 2/ 2015).

Wujud menumbuhkan sikap demokratis kepada siswa dilakukan FK (wawancara, 8/3/2016) dengan cara memimpin musyawarah kelas untuk menentukan pengurus kelas, role of class, jadwal piket kebersihan, dan program kelas yang ingin dilaksanakan siswa. Posisi beliau hanya sebagai pengarah sehingga keleluasaan musyawarah diberikan kepada siswasepenuhnya. Guru telah mendidik siswa untuk bermusyawarah dengan kesepakatan yang dapat diterima dan dilaksanakan oleh semua siswa.

\section{Keteladanan Semangat Kebangsaan dan Cinta Tanah Air}

Sekolah Islam Al Azhar Yogyakarta membiasakan warga sekolah untuk menyanyikan lagu Indonesia Raya setiap hari sebelum pembelajaran jam pertama dimulai. Semua warga sekolah secara bersama menyanyikan lagu Indonesia Raya dengan dipandu dan diiringi musik melalui pengeras suara yang dapat didengarkan di semua lingkungan sekolah, baik di dalam kelas maupun di luar kelas. Pada saat kegiatan ini, semua aktivitas di sekolah dihentikan dan seluruh warga sekolah mengambil sikap sempurna, berdiri tegak, dan bernyanyi bersama. Semua guru, pegawai, staf yayasan, petugas kebersihan hingga petugas keamanan sekolah wajib mengikuti pembiasaan ini. Bagi yang terlambat masuk lingkungan sekolah wajib menunggu di luar gerbang sekolah, karena gerbang pintu ma- 
suk ditutup selama 15 menit guna menghindari orang berlalu-lalang saat kegiatan ini berlangsung.

Kegiatan tersebut menjadi strategi pembinaan karakter untuk menumbuhkan semangat kebangsaan bagi siswa. BSD memanfaatkan kesempatan tersebut untuk menjadi teladan terdepan dalam menunjukan semangat kebangsaan. Dengan memimpin langsung menyanyikan Indonesia Raya. Cara lain yang digunakan untuk mengatasi kejenuhan saat siswa terlihat kurang bersemangat, beliau meminta semua siswa untuk berdiri dan bernyayi lagu-lagu nasional dengan dipimpin oleh siswa yang terlihat mengalami kejenuhan. $\mathrm{Hal}$ ini memiliki keuntungan berlipat, selain siswa kembali bersemangat, juga dapat tumbuh dalam dirinya rasa bangga terhadap lagulagu perjuangan dan lagu-lagu nasional.

Keteladanan semangat kebangsaan oleh guru Al Azhar berdampak terhadap antusiasmesiswa terhadap kegiatan-kegiatan yang bernuansakebangsaan. Seperti pada peringatan $\mathrm{H}$ ari Karini, semua siswa menggunakan baju pakaian adat Yogyakarta untuk melakukan upacara bendera sekaligus mengikuti perlombaan yang diadakan oleh sekolah masing-masing. Selain itu, setiap pagi siswa bersemangat menyanyikan lagu Indonesia Raya secara bersama-sama. Saat peneliti melakukan observasi (17/ 2/ 2016) tampak semua siswa dengan kesadaran masing-masing bernyanyi lagu Indonesia Raya secara baik dan benar.

Sebagai guru PKn yang ingin membina karakter cinta tanah air, BSD mengatakan bahwa langkah awal dengan menge nalkan simbol-simbol negara, mengagumi, dan menggunakan dengan selayaknya, se perti menanamkan rasa bangga terhadap bendera Merah Putih dan lambang negara Garuda Pancasila. Siswa diajarkan untuk mengaguminya daripada menggunakan lambang-lambang yang tidak sesuai dengan kepribadian bangsa dan bendera negara lain yang justru marak digunakan sebagai asesoris oleh remaja saat ini. Berdasarkan hasil pengamatan (25/2/2016) pada setiap kelas terdapat gambar atau poster burung Garuda, Presiden, dan Wakil Presiden Indonesia. Cara ini dimaksudkan agar siswa bangga terhadap tanah airnya.

Kegiatan Iain yang dilakukan adalah dengan menyanyikan lagu-lagu nasional sebelum pelajaran PKn dimulai. Kegiatan ini dipimpin oleh salah satu siswa dan dilakukan secara bergilir. Kebiasaan menyanyikan lagu-lagu nasional juga menjadi antisipasi terhadap trend remaja yang lebih suka dengan lagu-lagu dengan lirik yang berbau SARA, pornografi, dan tema percintaan yang tidak semestinya dialami oleh siswa.

\section{Keteladanan Karakter Cinta D amai}

Diperoleh databahwa ketika ada tingkah laku siswa yang mempunyai indikasi menggangu di dalam kelas, guru tidak memerintahkannya keluar dari kelas. Guru akan tetap berusaha membina dan pantang untuk mengeluarkan siswa dari dalam kelas karena semua siswa memiliki kesempatan yang sama di dalam kelas.

Menjadi sosok yang cinta damai dilakukan oleh AR dengan cara memanggil nama siswa dengan menambahkan kata sapaan yang halus (mas/mbak). Kebiasaan ini dilakukan untuk menciptakan rasa kedewasaan dan penghargaan bagi siswa. Guru pun tidak pernah memanggil dengan nama yang bukan sebenarnya. Cara ini sekaligus menjadikan contoh kepada siswa bahwa cara memanggil merupakan wujud toleransi terhadap sesama. Upaya ini menjadi antisipasi terhadap kebiasaan-kebiasaan siswa yang lebih suka memanggil nama temannya dengan nama samaran atau nama 
orang tuanya yang menjadi bahan celaan (wawancara, 8/ 10/ 2015). Selain itu, mewujudkan semangat cinta damai, menurut SF (wawancara, 15/ 3/ 2016), dimulai dari kontrol emosi/ amarah. Sesuatu yang dimuali dengan marah akan merusak hubungan persaudaraan dan menimbulkan rasa benci dan permusuhan. Begitu juga dengan guru yang harus berusaha menghindari katakata kasar dan amarah apabila menghadapi siswa yang nakal. Misalnya, beliau bersabar dan tidak marah ketika siswa berulah di dalam kelas yang dapat mengganggu kegiatan pembelajaran. Dengan nada yang halus dan ramah guru mengingatkan kepada siswa yang bersangkutan untuk kembali berkonsentrasi belajar didalamkelas. Untuk menjadi teladan yang cinta damai, SF juga berusaha menjadi sosok yang pemaaf dengan selalu memaafkan siswa yang sebelumnya melakukan kesalahan.

Dengan berbagai contoh keteladanan tersebut, siswa diharapkan mampu menciptakan dan menjaga hubungan baik serta menghormati guru, karyawan, pegawai, pelatih intrakurikuler dan ekstrakurikuler sesuai ajaran Islam. Selain itu, siswa diharapkan mampu menjaga hubungan baik dengan sesama siswa baik di dalam lingkungan sekolah maupun di luar sekolah. Peneliti juga mendapat sambutan dan sapaan yang bersahabat dari siswa di Al Azhar. Siswa menyapa sambil tersenyum kepada tamu yang hadir di sekolah. $\mathrm{Hal}$ ini menjadi buki bahwa siswa telah berusaha menjadi siswa yang bersahabat dengan siapa pun (observasi, 26/ 4/ 2016).

Saat berada di Al Azhar Yogyakarta (observasi, 7/ 3/ 2016), peneliti tidak menemukan kejadian siswa yang sedang berkelahi atau memaki sesama teman. Siswasiswa berbaur bermain bersama dan tidak pernah mengumpat dengan kata-kata kotor sekalipun saat bercanda. Berdasarkan penjelasan SF, potensi konflik antarsiswa selalu diantisipasi dengan baik oleh pihak sekolah. Oleh karena itu, konflik yang lebih besar tidak akan pernah terjadi. Berda-sarkan hasil pengamatan peneliti (3/ 2/2016), saat siswa berinteraksi dengan teman sebaya tidak pernah menggunakan nama samaran atau bahkan nama orang tua yang bermaksud menghina teman. Sesama siswa berbaur meski berbeda kelas dan berbeda jenjang kelasnya serta tidak terlihat adanya kesan siswa senior dan siswa yunior di sekolah. Fakta ini membuktikan keber-hasilan hidup berdampingan secara damai di Al Azhar.

\section{Keteladanan Karakter Peduli Lingkungan}

Peduli terhadap lingkungan dipahami oleh guru Al Azhar dengan menerapkan dan menjadi motor penggerak slogan LISA (Lihat Sampah Langsung A mbil). Wujud pelaksanaan slogan ini dengan menggambil sampah yang kemudian dimasukkan ke dalam tempat sampah yang sudah dipilah jenisnya. Seperti yang terlihat saat melakukan observasi (14/ 4/2016), BSD sedang mengambil daun kering yang berada di depan pintu ruang guru. Hal lain yang dilakukan beliau untuk menjaga kebersihan lingkungan dengan menata sepatu dan sandal yang kurang rapi, karena terkadang ada satu atau dua siswa yang masih belum terbiasa rapi. Guru pun tidak segan untuk mengambil sepatu dan sandal tersebut untuk diletakkan di tempat yang sudah disediakan di serambi masjid. Saat peneliti akan mengikuti salat Zuhur berjamaah, terlihat mayoritas siswa memasukkan sepatu atau sandal keloker yang tersedia.

Berdasarkan pernyataan BSD, semua warga sekolah wajib menjaga kebersihan lingkungan bukan semata-mata kebersihan menjadi tugas dari pekerja kebersihan sekolah sehingga lingkungan sekolah akan 
tetap bersih dan hijau. Sependapat dengan pernyataan tersebut, AR juga memberikan contoh keteladanan yang diharapkan dapat dicontoh oleh siswa. Salah satunya dengan menanam pohon, meski hal tersebut masih dilakukan minimal dua kali selama setahun. Tanaman yang menjadi prioritas adalah tanaman obat keluarga. Selain kegiatan tersebut, AR bersama guru-guru lain dan siswa datang ke sekolah lebih awal untuk merawat dan membersihkan tanaman yang ada di pot depan kelas, misalnya dengan menyirami dan membersihkan daun atau bunga yang sudah kering. Beliau menekankan bahwa seorang muslim wajib memiliki karakter cinta dan peduli untuk menjaga kebersihan dan menjauhkan diri dari sifat merusak lingkungan (wawancara, 8/ 12/ 2015).

Keteladanan oleh guru lain seperti yang dilakukan oleh $\mathrm{ARi}$ dengan cara membuang sampah dengan urutan yang benar. Beliau selalu memberikan contoh langkah membuang sampah dengan benar, yakni ambil sampah, menuju tempat sampah yang telah disediakan, berhenti tepat di depan bak/ tempat sampah, kemudian buka tempat sampah selanjutnya buang sampah tersebut. Langkah ini memastikan supaya sampah masuk ke dalam tempatnya. Langkah ini menghindari kebiasaan membuang sampah dengan cara dilempar atau sambil berjalan sehingga sampah terkadang tidak masuk dan berserakan. Terlebih Islam merupakan agama yang cinta akankebersihandan kesucian, dengan prinsipajaran bahwa kebersihan itu bagian dari iman.

SF (wawancara, 15/ 3/ 2016) menegaskan bahwa peduli terhadap lingkungan dapat dimulai dari kebersihan kelas. Ruangan kelas merupakan ruangan yang lebih sering digunakan untuk proses pembelajaran. Caranya dengan secara bersama-sama (guru dan siswa) memastikan samping kanan dan kiri, di bawah meja, di belakang, dan di laci meja belajar bersih dari sampah. A pabila masih terdapat sampah, siswa wajib mengambilnya dan membuang ke tempat sampah. Pelajaran akan dimulai apabila kelas dalam keadaan bersih. Saat peneliti melakukan pengamatan di lingkungan Al Azhar, tidak ditemukan sampah plastik sisa jajanan siswa, kertas, atau botol minuman. Gambaran tersebut menjadi bukti program LISA (lihat sampah langsung ambil) berjalan efektif di Al Azhar.

\section{Keteladanan Karakter Peduli Sosial}

Peduli terhadap sesama perlu menjadi karakter baik semua orang, tidak terkecuali siswa di sekolah. Sekolah menjadi salah satu bagian dari lingkungan masyarakat sekitar. Dengan demikain, sifat peduli perlu dikembangkan pada wargasekolah, terutama guru dan siswa, terlebih sekolah Al Azhar sebagai sekolah Islami harus lebih memiliki kepekaan dan kepedulian dengan masyarakat sekitar.

Sebagai guru AI Azhar, BSD mencoba mengembangkan sifat tersebut dalam kehidupan sehari-hari baik di sekolah maupun di lingkungan masyarakat. Misalnya saja beliau bersama guru-guru yang lain melakukan takziyah apabila mendengar kabar kematian, menjenguk warga sekolah yang sedang sakit, mengunjungi warga sekolah yang melahirkan. Terkadang apabila mendengar kabar kematian ketika pembelajaran PKn, beliau mengalokasikan waktu di akhir pembelajaran untuk salat gaib berjamaah dengan siswa di kelas yang sedang diampu dan kemudian berdoa bersama untuk yang meninggal.

Secara umum, AR juga telah melakukan hal yang sama. Sebagai wali kelas beliau selalu hadir untuk memberikan empati dan peduli terhadap keberadaan orang lain 
yang sedang membutuhkan. A pabila terdapat siswa yang izin karena sakit/ tertimpa musibah maka akan mengumumkan di depan kelas, kemudian memimpin doa bersama untuk yang sakit supaya diberi kesehatan. Selain itu, AR mengoordinasi untuk menjenguk dengan membawa buah tangan bagi siswa atau guru yang sedang sakit. Hal lain yang dilakukan adalah takziyah bersama apabila ada saudara dari siswa, guru, dan karyawan Al Azhar meninggal dunia. Selanjutnya, guna meningkatkan kepedulian sosial, guru Al Azhar juga berpartisiasi terhadap program one day one thousand, Jumat beramal, dan program pe duli umat lainnya, seperti menyumbangkan pakaian pantas pakai dan sembako untuk acara bakti sosial.

Paparan hasil penelitian tersebutmenjadi bukti bahwa siswa di sekolah memiliki kecenderungan untuk meniru apa yang dilakukan oleh guru. Dengan demikian, keteladanan menjadi penting untuk dapat ditiru/ dicontoh. Ketelatanan tersebut menjadi metode yang sangat efektif dalam upaya pembinaan karakter siswa. Dengan metode keteladanan, siswa akan lebih mudah menangkap pesan moral yang disampaikan oleh guru. Terlebih lagi siswa akan lebih suka meniru sosok guru yang diidolakan. Dalam hal ini Bajovic, Rizzo, \& Engemann (2009:18) menegaskan, "The importance of educators modeling good sets of values through these discussions may become of essence in developing moral action in students. Hal inilah yang menuntut guru untuk menjaga konsistensi keteladanan secara berkelanjutan baik sifat, sikap, dan tutur kata sehari-hari. Di sisi lain Jamaluddin (2013:188) mengungkapkan, "Character is one trait (habit) how to think, talk and behave. The positive attributes include enthusiastic, on time, and trustworthy should be reliable."
Dalam dunia pendidikan tersirat makna uswah atau keteladanan. Hakikat pendidikan merupakan proses mengagumi, meniru, dan mengambil yang benar. Seorang pendidik tidak boleh hanya sekedar memberi contoh kepada siswa-siswanya, tetapi harus menjadi contoh. Guru dapat membentuk kepribadian efektif dengan cara berperilaku yang menyenangakan kepada siswa dan menunjukkan keteladanan (Saidi, 2013:6). Dengan konsistensi keteladanan, siswa akan semakin yakin untuk meniru sosok guru yang diidolakan. Konsistensi tersebut memerlukan adanya keselarasan antara apa yang diucapkan dengan apa yang dilakukan sebagai upaya pengamalan nilai-nilai karakter yang ingin disampaikan kepada siswa. Hal yang perlu diingat bahwa membina karakter tidak hanya sekedar memberikancontohgambaran apayang harus dilakukan, tetapi menjadi contoh dalam kehidupan sehari-hari. Sosok yang diteladani dan yang meneladani merupakan komponen penting dalam pembinaan karakter. Hal ini dikarenakan interaksi guru dengan siswa merupakan kunci sukses pendidikan.

Guru Al Azhar dapat menekankan pentingnya nilai nilai adab yang dikembangkan oleh orang dewasa sebagai model, yang akan dicontoh oleh siswa dalam ke hidupan sehari hari. Guru adalah model teladan atau uswatun hasanah (Daryati, 2014: 10). Prinsip pendidikan yang dikemukakan Ki Hadjar Dewantara yang diperankan oleh guru yaitu tut wuri handayani, yakni dari belakang seorang guru harus memberikan dorongan dan arahan, ing madya mangun karsa, yakni di tengah atau di antara siswa, guru harus menciptakan prakarsa dan ide, dan ing ngarsa sung tulada, yakni di depan, seorang pendidik harus memberi teladan atau contoh tindakan baik. 
Peneliti menemukan kesesuaian antara hasil wawancara terhadap guru dan hasil observasi di lapangan. Keteladanan guru Al Azhar terbukti dilaksanakan dengan nyata, yang sebagian dari contoh keteladanan tersebut dapat diamati oleh peneliti. Contoh keteladanan tersebut terbukti menjadi strategi pembinaan karakter di Al Azhar karena siswa dengan penuh kesadaran tanpa harus diperintah/ diminta melakukan perbuatan dan kegiatan seperti yang dilakukan oleh guru. Pembinaan karakter melalui keteladanan guru terhadap siswa tidak secara langsung terjadi, namun meIalui proses pemberian contoh oleh guru terlebih dahulu, kemudian siswa mengikuti apa yang telah dilakukan oleh guru.

Keefektifan keteladanan terbukti dari hasil observasi peneliti bahwa siswa me nampilkan sikap, bertutur kata, dan berpenampilan dengan baik. Selain itu, siswa me lakukan tindakan-tindakan yang berkarakter tanpa harus ada perintah dari guru. Misalnya, saat salat berjamaah siswa dengan sendirinya bergegas untuk ke masjid. Siswa juga membuang sampah ke tempat yang sudah disediakan, bertutur kata halus saat bertegur sapa/ memanggil teman, dan menyanyikan lagu Indonesia Raya dengan sikap sempurna. Di samping itu, siswa juga selalu menjaga kelas selalu bersih, berkunjung ke perpustakaan saat istirahat, dan menyapa peneliti saat peneliti berada di lingkungan Al Azhar.

Hasil penelitian ini menunjukkan bahwa guru-guru PKn (dan guru-guru lain) di sekolah Al Azhar telah berusaha menjadi teladan dalam pembinaan karakter terhadap para siswa berdasarkan delapan belas karakter yang dianjurkan oleh Kementerian Pendidikan dan Kebudayaan. Karakter yang dominan diteladankan oleh guru PKn adalah religius, jujur, disiplin, gemar membaca, cinta damai, semangat kebangsaan, cinta tanah air, demokratis, pedui sosial, dan peduli lingkungan.

Pembinaan karakter di Al Azhar Yogyakarta melalui keteladanan guru jika dikategorikan sesuai dengan pembinaan karakter di sekolah oleh Kementerian Pendidikan dan Kebudayaan, maka dapat dikategorikan menjadi lima, yaitu: (1) pembinaan karakter yang berhubungan dengan Tuhan melalui keteladanan karakter religius; (2) pembinaan karakter yang berhubungan dengan kebaikan diri/ pribadi melalui keteladanan jujur, disiplin, dan gemar membaca; (3) pembinaan karakter yang berhubungan dengan sesama manusia melalui keteladanan demokratis, menghargai prestasi, dan cinta damai; (4) pembinaan karakter yang berhubungan dengan lingkungan sekitar melalui keteladanan peduli lingkungan dan peduli sosial; dan (5) pembinaan karakter yang berkaitan dengan bangsa dan negara melalui keteladanan semangat kebangsaan dan cinta tanah air.

Metode keteladanan seperti yang ditunjukkan guru di Al Azhar juga sesuai dengan gagasan Lickona (1997:67) yang menegaskan, "Cannot teach character unless they display character". Artinya, di dalam interaksi guru dengan siswa, sikap/ moralitas positif guru cukup berpengaruh. Guru dapat menjadi contoh pemodelan untuk membahas moral dengan mengambil peristiwaperistiwa penting yang terjadi dari kehidupan sekolah dan peristiwa saat ini. Guru tidak dapat mengajarkan karakter tanpa ia menampilkan karakter tersebut.

Guru-guru di Al Azhar telah berusaha menjadi teladan dalam pembinaan karakter melalui tindakan nyata, yaitu mengimplementasikan nilai-nilai karakter yang dikembangkan di sekolah. Upaya tersebut sejalan dengan pendapat Syamsu (2012: 226), yakni "One effort that can be done is building character of students through maxi- 
mizing the role of teachers". Keberhasilan pembangunan karakter siswa membutuhkan contoh keteladanan atau model dari guru.

\section{PENUTUP}

Berdasarkan paparan deskripsi hasil penelitian dan pembahasan, dapat disimpulkan bahwa pembinaan karakter melalui keteladanan guru Pendidikan Kewarganegaraan di Sekolah Islam Al Azhar Yogyakarta diawali dengan memantapkan karakter pribadi guru terlebih dahulu. Selanjutnya, keteladanan diwujudkan dengan cara bertutur kata, bersikap, memiliki sifat, dan berpenampilan yang sesuai dengan karakter religius, jujur, disiplin, demokratis, semangat kebangsaan, cinta tanah air, menghargai prestasi, cinta damai, gemar membaca, peduli lingkungan, dan peduli sosial yang dilakukan secara berkesinambungan. Diyakini oleh para guru bahwa dengan menjadi guru yang berkarakter, siswa akan merasa memiliki panutan atau model dalammewujudkan pribadi muslim yang berkarakter dan berbudaya ketimuran sebagai ciri khas pendidikan Al Azhar.

\section{UCAPAN TERIMA KASIH}

Dengan dimuatnya tulisan ini dalam Jurnal Pendidikan Karakter edisi ini, penulis mengucapkan terima kasih atas bantuan dari berbagai pihak mulai dari saat proses penelitian hingga terselesaikannya tulisan ini. Ucapan terima kasih terutama disampaikan kepada Bapak dan Ibu Guru Sekolah Islam Al Azhar Yogyakarta yang telah bersedia memberikan data penelitian secara lengkap sehingga penelitian dapat terselesaikan. Ucapan terima kasih juga disampaikan kepada anggota Dewan Redaksi Jurnal Pendidikan Karakter yang telah merevieu dan menyetujui pemuatan tulisan ini.

\section{DAFTAR PUSTAKA}

Arthur, J., Davies, I., \& Hahn, C. 2008. "Educating for Civic Character". The SAGE Handbook of Education for Citizenship and Democracy: Educating for Civic. Thousand Oaks, CA: Sage, pp. 399-410.

Arthur, J., Davison, J., \& Lewis, M. 2005. Professional $V$ alues and Practice $A$ chieving the Standards for QTS. London and New York: Routledge Falmer.

Bajovic, M., Rizzo, K., \& Engemann, J. 2009. "Character Education Reconceptualized for Practical I mplementation".J ournal of Educational Administration and Policy, Issue 92, March 14, 2009, pp. 123.

Coughlan, S. 2015. "A sia Peringkat Tertinggi Sekolah Global, Indonesia Nomor 69". M ajalah Pendidikan BBC, 13 Mei 2015. http:// www.bbc.com/ indonesia/ majalah/ 2015/ 05/ 150513_majalah_asia_sekolah_terbaik. Diakses Tanggal 30 Oktober 2015.

Daryati, H. 2014. Pengel olaan Pendidikan Karakter di SD AI Azhar Syifa Budi Surakarta. Naskah Publikasi, Program Pascasarjana Universitas Muhammadiyah Surakarta, hlm. 1-12.

Djaelani, A. R. 2013. “Teknik Pengumpulan DatadalamPenelitian Kualitatif". M ajalah IImiah Pawiyatan, Vol. XX, No: 1, Maret 2013, hlm. 82-92.

Jamaluddin, D. 2013. "Character Education in Islamic Perspective". International Journal of Scientific \& Technology Research, Vol. 2, Issue 2, February 2013, pp. 187-189.

Karim, A. G. 2012. The U langan was Easy. http:/ / agkarim.staff.ugm.ac.id/ 2012 
/ 11/ 05/ the-ulangan-was-easy-/ comment-page-1/. Diakses Tanggal 17 Agustus 2015.

Kirschenbaum, Howard. 1995. 100 W ays to Enhance $V$ alues and $M$ orality in Schools and Youth Settings. Massachusetts: Allyn \& Bacon.

Lickona, T. 1997. “The Teacher's Role in Character Education". Jurnal of E ducation, Boston U niversity, Vol. 179, Number 2, 1997, pp. 63-80.

Moleong, L.J. 2007. M etodologi Penelitian Kualitatif. Bandung: PT Remaja Rosdakarya.

Saidi, A. 2013. “Pendidikan Islam \& KetauIadanan". Warta Al Azhar, Edisi 261 Januari 2013, hlm. 6-11.

Samsuri. 2012. Pendidikan Karakter W arga N egara: K ritikPembangunan Karakter Bangsa. Surakarta: Pustaka Hanif.

Setyawan. 2014. Tawuran Pelajar M emprihatinkan Dunia Pendidikan. http:/ / www.kpai.go.id/ artikel/ tawuran-pelajar-memprihatinkan-dunia-pendidikan/ . Diakses Tanggal 17Agustus 2015.

Setyawan. 2015. Pelaku Kekerasan terhadap Anak Tiap Tahun M eningkat. http:/ / www.kpai.go.id/ berita/ kpai-pelaku-kekerasan-terhadap-anak-tiap-tahun-meningkat/ . Diakses tanggal 17 Agustus 2015.

Siagian, L. 2013. “Kontribusi Pembelajaran PKn dalam Upaya Pencegahan Terjadinya Kenakalan Remaja". Jurnal Citizenship, tahun 2013, hlm. 18-34.

Sudiatmika, I.A.R. 2013. “Studi Pendahuluan Pengembangan Model Pendidikan Budi Pekerti Berlandaskan Filosof Trikaya Parisudha di SMP". Disampaikan dalam Seminar N asional Riset Ino- vatif I: Memperkuat Jati Diri Bangsa Melalui Riset Inovatif, Unggul, dan Berkarakter. Singaraja: Universitas Pendidikan Ganesha.

Sugiyono. 2013. M etode Penelitian Pendidian: Pendekatan Kuantitatif, Kualitatif, dan $R \& D$. Bandung: Penerbit Alfabeta.

Sujatmiko, T. 2015. “Kenakalan Remaja Kian Kompleks". Kedaulatan Rakyat. http:/ / www.krjogja.com/ web/ news/ rea d/ 253063/ kenakalan_remaja_kian_k ompleks. Diakses tanggal 17 Agustus 2015.

Supeni, S. \& Saddhono, K. 2013. “Cognitive Behavior has Replaced the Javanese Traditional Values in Global Era". A sian Journal of $M$ anagement Sciences and Education, Vol. 2 No. 2, April 2013, pp. 156-162.

Syamsu, A. K. 2012. "Character Education and Students Social Behavior". J ournal of Education and Learning. Vol.6, No. 4, pp. 223-230.

Triyansyah, A. 2015. M enyekolahkan A nak di Sekolah U nggulan, Prestise atau Bukan? http:/ / www.kompasiana.com/ adea ntriyansyah/ menyekolahkan-anakdi-sekolah-unggulan-prestise-ataubukan_551b96ff8133114c549de0f0. Diakses tanggal 17 Agustus 2015.

Undang-Undang Nomor 20 Tahun 2003 tentang Sistem Pendidikan N asional.

Widyaningsih, T. S., Zamroni \& Zuchdi, D. 2014. "Internalisasi dan Aktualisasi Nilai-N ilai Karakter pada Siswa SMP dalamPerspektifFenomenologis".Jurnal Pembangunan Pendidikan: Fondasi dan A plikasi, Vol. 2, No. 2, hlm. 181195. 